\title{
Carbon Gold Rush and Carbon Cowboys: A New Chapter in Green Mythology?
}

\author{
Brigitte Nerlich and Nelya Koteyko
}

Individual and collective efforts to mitigate climate change in the form of carbon offsetting and emissions trading schemes have recently become the focus of much media attention. In this paper we explore a subset of the UK national press coverage centered on such schemes. The articles, selected from general as well as specialized business and finance newspapers, make use of gold rush, Wild West and cowboy imagery which is rooted in deeply entrenched myths and metaphors and allows readers to make sense of very complex environmental, political, ethical, and financial issues associated with carbon mitigation. They make what appears complicated and unfamiliar, namely carbon trading and offsetting, seem less complex and more familiar. A critical discussion of this type of imagery is necessary in order to uncover and question tacit assumptions and connotations which are built into it and which might otherwise go unnoticed and unchallenged in environmental communication.

Keywords: carbon offsetting, emissions trading, gold rush, cowboys, metaphors, frames

Brigitte Nerlich is Professor of Science, Language, and Society at the Institute for Science and Society, School of Sociology and Social Policy, at the University of Nottingham. Dr Nelya Koteyko is a Research Fellow at the Institute for Science and Society, School of Sociology and Social Policy, University of Nottingham. Correspondence to: Institute for Science and Society, University of Nottingham, West Wing, Law and Social Sciences Building, University Park, Nottingham NG7 2RD, UK. Email :

Brigitte.nerlich@nottingham.ac.uk

"Through the labor of mining, gold seekers forged new connections to nature, but they forged those connections within the powerful context of their culture" (Morse,

2003, 137).

\section{Introduction}


The issues of global warming and climate change have recently attracted immense media coverage. Advice on how to reduce one's "carbon footprint" is provided almost daily in newspapers, adverts, books and on international, governmental and non-governmental websites. Much of the discourse in these media uses a variety of "carbon compounds"-lexical combinations of at least two roots--such as "carbon finance," "carbon sinner," "low carbon diet," or, indeed "carbon cowboy" and "carbon gold rush." In 2006, the Oxford Dictionary of American English chose "carbon neutral" as its "word of the year," and "carbon emission," “carbon sink," "carbon sequestration," "carbon tax," "carbon credit," "carbon trading," "carbon offset" and, of course, "carbon footprint" are now listed in the online version of the Oxford English Dictionary (OED, online). These are only some of the numerous lexical and metaphorical clusters that have emerged in English speaking countries around carbon as the hub. A whole new language is evolving that needs to be monitored and investigated in order to discover how climate change is framed by various stakeholders, how public attitudes and perceptions are shaped and what solutions to climate change and global warming are put forward. ${ }^{1}$

In this article we investigate how some of these carbon compounds, such as "carbon gold" or "carbon gold rush," their variants, such as "green gold" and "green gold rush," and the metaphors, scenarios and narratives associated with them, are used in the UK national press coverage of carbon-offsetting schemes. The OED added the compound "carbon offset" as an entry in 2008 and defines it as "an action or process (typically the planting of trees) which counteracts or is claimed to counteract the emission of carbon dioxide resulting from industrial or other human activity" and, in a second sense, as "a quantifiable amount of such action as a tradable commodity." "Carbon footprint" is defined as "the environmental impact 
of carbon emissions; the magnitude of this for a particular individual, organization, or community" (OED, online).

Although climate change is a global public issue, there are great differences between how nations respond to the challenges it poses. We focus here on the UK as climate change is discussed here (Carvalho, 2005; Carvalho \& Burgess, 2005) in quite different ways compared to the US (Boykoff \& Boykoff, 2007) and Europe (Brossard et al, 2000; Weingart et al, 2000). Press coverage was chosen as the basis for this article, since the print media provide a major location where the strategic and implicit metaphors employed by different actors in the climate change debate are filtered into the public domain. They are still a major site of what Petersen (2005, p. 203) calls the "politics of the definition of public issues."

Trying to make sense of carbon offsetting is not easy, as there are a multitude of policies, options and economic, political and ethical implications which need to be understood. One way of making sense or forging an understanding of complex and rather abstract issues is through the use of metaphors and images, which again, can be linked to well-known myths and narratives. As early as 1644, the Italian philosopher, rhetorician and historian Giambattista Vico (1948) pointed out that metaphors are like myths in miniature. In 1957 the French literary critic Roland Barthes noted in Mythologies (Barthes, 1970) that myths are not just imaginative and "untrue" tales, but that we use them in everyday life to make sense of the world around us. As a dwarf points out in Terry Pratchett's Wintersmith: “A metaphor is a kind o' lie to help people understand what's true" (Pratchett, 2007, p. 340). Through such cultural narratives we structure our views of the world and make it seem "natural" for us. Lakoff and Johnson noted in 1980 that "Like metaphors, myths are necessary for making sense of what goes on around us [...] just as we often take the metaphors of our own culture as truths, so we often take the myths of our own culture as 
truths” (p.185-186). In our case, mythologising carbon offsetting in terms of two images, metaphors and narratives, namely gold rush and cowboy imagery, will be explored as sensemaking strategies in an often confusing, complex and predominantly economic context.

The use of figures of speech, such as gold rush, to make sense of social and economic issues in the media and in advertising has been around for a long time, as we shall see in the next section. However, as Mühlhäusler (1999) notes, "the use of metaphor to reconcile economic and moral discourse about the environment" (p. 179) can be seen as a more recent discursive strategy that deserves closer investigation. This paper aims to highlight these complex links between nature, culture, history and rhetoric by studying the use of entrenched cultural frames and imagery used in communicating about climate change mitigation activities.

\section{Background: Central Concepts}

\section{Carbon Offsetting}

Carbon offsetting as an action which is claimed to counteract the emission of carbon dioxide seems at first sight to stand in a long tradition of environmental activism. However, as we have seen, the OED also points to another meaning of carbon offset, namely, as a quantifiable amount of such action as a tradable commodity. As the UK government points out on its website: "Carbon offsetting involves calculating your emissions and then purchasing "credits" from emission reduction projects that have prevented or removed the emission of an equivalent amount of carbon dioxide elsewhere" (DEFRA, 2005). This links 
up carbon offsetting with another tradition, more akin to green consumerism than green activism. As Mühlhäusler pointed out in 1999:

[... ] this elaborate change in ideological emphasis by corporate political discourse is very significant. What has changed in the social imagination of ecology and environmentalism that makes these astounding rhetorical ploys not only possible, but also apparently somewhat convincing? [ . . ] one vitally important change was the domestication of some types of ecological radicalism as “green consumerism” (Mühlhäusler, 1999, p. 168).

The green ambiguity surrounding carbon offsetting, as an environmental good or a consumer good, was brought home to us when a colleague sent us the invitation he had received to participate in a World Carbon Emissions Reduction Summit in Abu Dhabi in October 2008. The invitation began with the question: "Why should you miss the gold rush?" (Mike Hulme, p.c.).

Reducing carbon emissions is no longer the sole ambition of green individuals who want to do the ethically or morally right thing; instead carbon reduction activities have become part of a growing environmental commodity market (Clean Air-Cool Plant, 2006, p. i). In fact, the atmosphere may have become the most valuable resource on Earth, worth orders of magnitude more to society than it costs as a hazard (Thornes \& Randalls, 2007). The ambivalent framing of carbon offsetting schemes as good or bad (and this in different financial or moral senses) demonstrates how "commodification of carbon spawned a new industry around offsetting and CDMs [clean development mechanisms] without fully interrogating the bases and values implicated in this commodification in the first place." As we argue further in this article, metaphor analysis can provide a tool for such an interrogation. 
Goldrush, Wild West and Cowboy Imagery

The expression "gold rush" provides a rich imagery capable of illustrating stories of wild riches to be found in new and uncertain territory but also cautionary tales of lost dreams, trickery and the devastation resulting from the exploitation of nature and of other cultures. Gold rushes have occurred, for example, in Alaska, South Dakota, Australia, Chile, and British Colombia, but perhaps the most famous gold rushes were the California gold rush of $1848 / 49$ and the Klondike gold rush of 1898 . Both have generated a host of images, myth and narratives (see Smith, 195078) that still resonate with modern Western culture and modern life. Although myths and legends of gold rushes, the Wild West and the Western frontier have their strongest roots in the United States and have shaped American ideals and American morals (see Turner, 1920), they have become a common cultural heritage, especially through Wild West novels (by Charles Fenimore Cooper or Zane Grey for the USA and Karl May ${ }^{2}$ for Germany, for example) (see also Fussell, 1965), movies and television series. In this context, a reviewer of Kathryn Morse's 2003 book The Nature of Gold: An Environmental History of the Klondike Gold Rush, pointed out that:

The Klondike gold rush is perhaps better known as a metaphor than as an actual event. For some, it symbolizes the folly of human nature, the willingness of people to do anything, to go anywhere, in pursuit of gold. Here, one needs only see the photograph of prospectors trudging up Alaska's Chilkoot Pass, their supplies strapped to their backs, their bodies arched forward as they march into the snow-blown nothingness of the arctic. The image conveys the only necessary detail: fired by greed, Americans will do the darnedest things. For readers of the gold rush's most famous writer, Jack 
London, the Yukon wilderness made the event a symbol of struggle and survival: tales of men battling wind chill and frostbite; social Darwinist novels of citified pets unleashed by 'the wild's' call to compete, to become dogsled team leaders, to run at the head of the wolf pack (Roberts, 2004).

In terms of popular culture, gold rush imagery is rooted in the romanticized, mythological or metaphorical rather than the real aspects of the gold rush, as popularized in legends, songs and art work (see Blodgett, 1999; Driesbach, et al., 1998). The romantic aura surrounding gold rush stories popularized in Westerns emphasizes adventure, risk-taking and, most importantly, limitless opportunities. However, more recently historians have pointed out that this quest for gold could also have negative consequences for the people who engaged in it, for the animals they used and the land or environment they conquered (see Morse, 2003). These more negative connotations can be used in discourses that disapprove of behavior fuelled by greed and unrestricted by any rules. Such pejorative connotations are, by contrast, more directly associated with the term "cowboy." As Henry Nash Smith (1978 $\underline{1950)}$ notes in his book Virgin Land: The American West as Symbol and Myth, the cowboy as Wild West hero first evoked rather positive associations, such as braveness, generosity and honesty. However:

As late as $1881[\ldots]$ the pejorative connotations of the term "cowboy" were still uppermost. President Chester A. Arthur's First Annual Message to Congress mentioned a disturbance of the public tranquility by a band of "armed desperadoes known as “Cowboys," probably numbering from fifty to one hundred men," who had for months been committing acts of lawlessness and brutality in the Territory of Arizona, and across the border in Mexico (Smith, 195078, p. 109-110). 
This pejorative usage has given rise to a more recent image of the cowboy as a fraudster, as in "cowboy builder," for example. The "cowboy economy," a phrase coined by the economist Kenneth Boulding in the 1960s, is similarly negative. The cowboy metaphor symbolized the "illimitable plains" on the one hand and the "reckless and exploitative" behavior of American economic activity on the other. The phrase "refers to how once booming industrial towns became abandoned after industries became obsolete or were relocated to other areas - leaving the buildings and people behind" (Beckley, 2005). To avoid a cowboy economy some advocate a cautious approach towards economic development and emphasize the danger that economic development could pose to future generations.

The framing of a story in terms of "gold rush," "Wild West" and "cowboy" imagery can therefore work in two different ways. These images can either be used to highlight the riches to be made or else to warn against financial and other pitfalls.

\section{Method and Conceptual Framework}

This study uses insights from metaphor research rooted in the cognitive linguistic tradition. Since the publication of Lakoff and Johnson's seminal book Metaphors We Live By (1980), it has become clear that metaphor is much more than a rhetorical device used poetically or a linguistic aid to explanation. Metaphors are pervasive in everyday life, shaping both how we think about and understand the world on an epistemological level and how we see and act in the world on an ontological level. They frequently draw on, and are reflective of, shared cultural narratives and myths and resonate with the larger social themes to which journalists in particular tend to be acutely sensitive (Iyengar, 1987). 
As metaphors suggest what is relevant about an issue, and also, as a result, what can be ignored, they share many features with what some analysts have called "frames." Like frames they "are principles of selection, emphasis and presentation composed of little tacit theories about what exists, what happens, and what matters" (Gitlin, 1980, p. 6). In this process of selective emphasis on causes and (often moral) consequences, the issue itself often appears deproblematized. What is strange and unfamiliar, such as carbon offsetting, becomes familiar in this process of metaphorisation and framing. It can also take on positive or negative connotations depending on the effect that journalists and others try to achieve when using a metaphorical framing device. From this perspective, metaphor analysis is closely related to a sociological perspective on framing that deals with precisely how issues are constructed, discourses structured, and meanings developed (Reese, 2003, p.7).

Although most metaphor and frame analysts point out that metaphors are usually used tacitly, some metaphors are less tacit than others. If a journalist or commentator talks about the fact that the battle against cancer is failing, the underlying so-called conceptual metaphor DISEASE MANAGEMENT IS WAR, according to which we map the source concept or conceptual domain of war onto the target one of disease management, goes almost unnoticed (see Lakoff \& Johnson, 1980). There are however other metaphors which are more consciously chosen to frame an issue, such as for example the metaphor created by Richard Dawkins: the selfish gene (Dawkins, 1976). In between these extremes lie what some have come to call discourse metaphors (Zinken et al., 2008), which prominently structure a discourse about a socially, culturally or politically salient topic over a certain period of time, but usually lack a prominent creator. They are part of our metaphorical framing legacy so to speak and can be made discursively salient for certain purposes. 
The source concepts of discourse metaphors refer to phenomenologically salient real or fictitious objects that are part of interactional space (i.e., can be pointed at, like MACHINES or HOUSES) and/or occupy an important place in cultural imagination (such as Frankenstein or gold rushes or the Wild West); and, conversely, discourse metaphors themselves can highlight or hide salient aspects of a socially, culturally or politically relevant topic, such as climate change.

The source concepts used in discursive metaphorical framing can be organized into mini-narratives through metaphor scenarios. A scenario is

\section{[. . .] a set of assumptions made by competent members of a discourse community} about 'typical' aspects of a source-situation [e.g. gold rush], for example, its participants and their roles, the 'dramatic' storylines and outcomes, and conventional evaluations of whether they count as successful or unsuccessful, normal or abnormal, permissible or illegitimate, etc. (Musolff, 2006, p. 28).

Building on work done on discourses around foot and mouth disease (see Nerlich, 2004) and avian influenza (Nerlich \& Halliday, 2007; Koteyko et al., in press 2008), this paper examines the use of two metaphor scenarios in discourses around carbon offsetting, namely the scenarios associated with "gold rush" and "cowboy" during a period of increased media attention to climate change. The gold rush scenario activates a set of assumptions made by competent members of a discourse community about typical aspects of this overall metaphorical frame, such as "adventure," "getting rich quick," "opportunity," "greed," "gold fever," but also "calamity" and "ruin," "boom" and "bust," "exploitation," "treachery," and "risk." The cowboy scenario can activate assumptions about a "rough and outdoor life," "wildness," and "braveness," but also, and in Britain perhaps more prominently than in the United States, "recklessness," "brutality" and "lawlessness." 
These narratively linked metaphor scenarios seem to provide a stable stock of metaphors, stories and images that exhibit high conceptual entrenchment and international appeal, and which are very familiar and easy to access and understand. They have been used in the past to frame scientific breakthroughs and economic opportunities, in, for example, genetics, genomics, stem cell research, nanotechnology (see Lux Research report, 2005), organic food production (Hallwell, 2001) and biofuels, an issue that shares the "gold rush" metaphor with the framing of carbon offsetting scheme explored here ${ }^{3}$ :

As the search for alternative energy sources gathers pace and urgency, the jatropha ${ }^{4}$ has provoked something like a gold rush. Last week BP announced that it was investing almost $£ 32$ million in a jatropha joint venture with the British biofuels company D1

Oils (Anonymous, The Times, 278/July/2007).

There was talk of a stem cell gold rush in California in 2004 (Philipkoski, 2004) and of bioprospecting with relation to genomics in 2005. In the bioprospecting debate the same phrase now used with respect to carbon is employed with reference to genetic data derived from plants:

In some ways, they are the Indiana Joneses of the 21 st century. Bioprospectors head into the deepest parts of the jungle, scale the highest mountains and, generally, brave extreme conditions in their quest for "green gold" -- plants and animals with commercially valuable properties. With the Amazon alone harboring medicinal plants capable of treating anything from parasite infections to malaria, toothaches to diabetes, the potential rewards are astronomical. But who will reap them? (Hooper, 2005)

After the carbon gold rush, future issues in science and society will continue to be framed in terms of gold rush, Wild West and cowboys, as these frames seem to have an enduring cultural appeal and are very much entrenched in capitalist societies. In this article we 
investigate how they were used to frame an emerging issue, namely carbon offsetting and what this might mean for the way that this issue is understood and discussed in the UK national press.

\section{Data}

The cowboy and gold rush imagery first attracted our attention when we began to study the use of the keywords carbon, trading and offset in the UK national press during the last decade (1996-2006), in order to gauge the UK national press reaction to these issues, and their framing of them ${ }^{\underline{5}}$.

A search using Lexis Nexis Professional revealed an increasingly frequent use of these terms towards the end of the decade, paralleled by the increase in creativity around the noun carbon mentioned above (e.g. the appearance of word combinations like carbon footprint and carbon cowboy). A closer reading of these articles revealed that one theme needed to be investigated in more detail, namely the issue of what one might call green finance, lexically instantiated by such combinations as "green gold," "green gold rush" and "carbon cowboy." We also found that many articles in the UK national newspapers made reference to other articles published in the Financial Times (FT) which is not covered by the Lexis Nexis database.

We therefore decided to examine the use of the "gold rush" and "cowboy" imagery more closely across two sets of news coverage: general newspapers and specialized news editions focusing on the coverage of business and financial issues. To explore the framing of carbon offsetting and emissions trading in the economic discourse we collected a corpus of 41 FT newspaper articles, 23 Business Week articles and 4 articles published in the monthly magazine Environmental Finance using the query "carbon AND gold rush OR carbon 
cowboy" without time restrictions ${ }^{6}$ (referred to from now on as "Finance corpus"). The same search query was then used to collect a corpus of 77 UK newspaper articles sourced from both national and local newspapers from the Lexis Nexis Professional database (from now on "UK newspaper corpus"). We first study the use of gold rush metaphors (predominant in our Finance corpus) and then proceed to explore the use of cowboy imagery that dominated the UK newspaper coverage.

\section{Analysis}

The 1997 Kyoto protocol (see http://ec.europa.eu/environment/climat/kyoto.htm) and its 2005 ratification have stimulated public awareness of climate change and its impact. In the UK such awareness was further increased after the publication of the Stern Review on the Economics of Climate Change released on October 30, 2006 by the economist Lord Stern of Brentford for the British government, which discusses the effect of climate change and global warming on the world economy (Stern, 2007). At the same time there has also been a surge in both consumer demand and investment in "green" products and with it came new market opportunities and opportunities for surplus capital. A day before the publication of the Stern report the Sunday Times reported for instance that:

Being green is good business. According to a report this year by the Institute of Grocery Distribution, more than half of British shoppers care about the green credentials of what they buy (Sunday TimesO'Connelll and Ringshaw, 29/October/2006). 
At the consumer end, the fastest growing and most controversial area of the emergent green market has been in the provision of carbon offsets to individuals, organizations and companies that have no emission reduction requirements under the Kyoto Protocol but who, for various reasons, are still keen to lighten their carbon footprint by financing a variety of carbon mitigation schemes such as forestry, renewable energy and energy efficiency projects.

These schemes are attracting increasing investment on the one hand and increasing criticism on the other. Some question their environmental effectiveness, some doubt their ability to push individual and collective lifestyles in a more sustainable direction, some have launched an outright attack on their business practices

(http://www.carbontradewatch.org/www.carbonwatch.org) and some have begun to question their "carbon ethics" and called for economists to speak up ${ }^{7}$. In the context of increasing investment, a preferred framing device is the gold rush metaphor with its associated myths and legends. In the context of increasing criticism, one of the preferred framing devices is the "cowboy" metaphor. When studying our two corpora, we found that the financial corpus uses, not surprisingly, the gold rush metaphor more frequently than the cowboy one, whereas in the UK newspaper corpus the cowboy metaphor is the dominant framing device.

The Use of Gold Rush Imagery in the UK National Press

Shortly after the publication of Stern report The Times told the following rags to riches story the under the headline, "The green goldrush that is creating multimillionaires":

NEIL ECKERT gave up his job as an insurance industry executive last year to dedicate his life to saving the planet. But unlike many sandal-wearing green campaigners, his 
good intentions did not come at a price. Rather, they have turned him into a multimillionaire.

Mr Eckert, 44, who lives in Sussex with his wife and children, is one of a new breed of green entrepreneurs who are living proof of Tony Blair's claims that tackling climate change is as much an opportunity as a threat. The company he co-founded and where he is chief executive, Climate Exchange PLC, dominates the market in carbon emissions trading, part of the green goldrush that was created by the Kyoto climate change treaty (The Times,Browne, 4/November/2006).

People are not urged to become green activists but green entrepreneurs. A year later this boom still continued $^{8}$ :

Today just about every sizeable investment bank -from Goldman Sachs to JP Morgan and the French bank Calyon -has plunged into trading carbon credits and emissions certificates in what some have dubbed a "green gold rush". The market, at about €40 billion ( $£ 27$ billion) a year, may be small compared with foreign currency or bond trading, but it is hot (Sunday TimesDavey, 15/July/2007). Both the FT articles and some articles from our UK newspaper corpus (predominantly on the business and financial pages) were telling exciting stories of profits waiting to be discovered by using such metaphorical creations as "green gold," "carbon gold," "green gold rush" or simply "green rush":

"It's a carbon gold rush," he says. "It's very easy to set yourself up as a carbon offset provider . . . It's a booming industry" (Harvey(FT, 26/April/ 2007).

The growing political salience of environmental politics has sparked a "green gold rush," which has seen a dramatic expansion in the number of businesses offering both companies and individuals the chance to go "carbon neutral," offsetting their own 
energy use by buying carbon credits that cancel out their contribution to global warming (FTBream et al, 26/April/ 2007).

Investing Wisely in the Green Rush. Venture capitalists are flocking to clean energy startups. [Headline] (HollandBusiness Week, 5/April/2007).

Here the "gold rush" metaphor scenario is employed entirely positively to connote opportunity and fortune. If there are warnings, they are about minimizing the risk of engaging in the "carbon gold" business, and are directed not at individual consumers of carbon-offsetting schemes but at organizations and companies - higher level players in the carbon trading market: "I'm not saying all is golden with green tech. There are some risks, as with any emerging market, for venture investors and the public markets" (Business WeekHolland, 5/April/2007). (It is not surprising then that we found only 5 uses of "carbon cowboys" in this corpus).

These business and finance oriented articles primarily deal with the commercial and investment opportunities created by the drive to mitigate climate change and, to a much lesser extent, green consumerism and corporate social responsibility initiatives. They take a strictly business stance and climate change's environmental and human impacts are not often acknowledged; they merely speak of its financial ones. This perhaps helps fuel concerns that the carbon markets are increasingly distancing themselves from their original environmental purpose, earning "fortunes for speculators" whilst delivering "little or no benefit for the environment" (GuardianDavies, 02/June/2007).

Despite this, as with gold, and then genes, the atmosphere is being increasingly considered as a global commodity to be bought and sold (Thornes \& Randalls, 2007), and many are looking to cash in regardless of the debated environmental benefit. As Neil Woodford, described as one of the "most revered fund managers in Britain," said the carbon 
market is set to become "the single biggest commodity market in the world" (Collinson, 2007). The following quotes illustrate how the generally alarmist climate change discourse (Hulme, 2007) is gradually being transformed into a promissory discourse of profits and high-yield investments:

Green is good [Headline] (The TimesAnonymous, 28/October/2006).

Carbon traders win in rush to be green [Headline] (The Times Jameson, 28/June/2006).

How green turned into gold: Shares in companies fighting climate change are soaring on the London Stock Exchange. Critics call it "green fever," but it's hard-nosed investors who are driving this particular bandwagon (The GuardianCollinson, 2/June/2007).

Whilst carbon emissions and the atmosphere are rather intangible as commodities and the voluntary offset market exists principally in the virtual context of the Internet, there exists a very concrete geographical center for the carbon market - the booming trade in emissions has its very own boom town: London (Sunday TimesMacCrone, 07/August/2005). Dubbed "The

Green Klondike" (Lofthouse, 2007), London has become one of the major financial centers of the carbon trade. Its investors are seen as more receptive to green technologies than their American counterparts (Sunday TimesO’Connell and Ringshaw, 29/October/2006).

The rising fever surrounding the carbon markets, as well as those for renewable energy and clean technologies, is akin to that for gold. New opportunities are arising, not just for the independent innovators hoping to strike it rich with their green ideas but also, and perhaps more securely, for large banks, investment companies and seasoned market traders, who are all in high demand as the carbon economy takes off. As one article, which uses gold rush imagery in a similar manner to discuss e-commerce investments, observed, "It wasn't 
the miners who got rich, it was the people who sold the picks and shovels" (Business WeekKharif, 11/November/2004).

However a Financial Times investigation also uncovered widespread failings in the new markets for greenhouse gases, suggesting some organizations are paying for emissions reductions that do not take place. Others are reported as making big profits from carbon trading for very small expenditure and in some cases for clean-ups that they would have made anyway:

Companies and individuals rushing to go green have been spending millions on "carbon credit" projects that yield few if any environmental benefits. A Financial Times investigation has uncovered widespread failings in the new markets for greenhouse gases, suggesting some organizations are paying for emissions reductions that do not take place. Others are meanwhile making big profits from carbon trading for very small expenditure and in some cases for clean-ups that they would have made anyway.

The growing political salience of environmental politics has sparked a "green gold rush," which has seen a dramatic expansion in the number of businesses offering both companies and individuals the chance to go "carbon neutral," offsetting their own energy use by buying carbon credits that cancel out their contribution to global warming (FTㅂeam et al, 26ㄱ/April/2007).

A letter to the FT expressed, albeit in an ironical way, similar disquiet about some offsetting schemes and about reconciling, as Mühlhäusler (1999) had noted, economic and moral discourses about the environment:

I found a wonderful scheme on the internet through which I can offset my lack of concern about the environment, by paying a man in Hyderabad to care about it for me. 
For little more than $£ 30$ a year, Rahul will feel deeply angst-ridden about global warming, allowing me to carry on not giving a toss. [. . .] This moral offsetting should not be confused with carbon offsetting. Rahul does not do anything. He is not planting trees or erecting wind farms. He simply wears a green wristband and wanders around muttering 'oh dear, oh dear, those poor polar bears'; and his angst means I can engage in guilt-free indifference. [. . .] There are a wide range of moral offsetting schemes available. However, this does mean there are cowboys out there. There are instances of people who have taken the money but have then not actually cared. Others are doublecounting their compassion. [. . .] (FT Shrimsley, 5/July/2007).

The Use of Cowboy Imagery in the UK Press

In the business newspaper articles studied so far we have seen how "carbon" has become a financial commodity framed in terms of gold and that schemes invented to mitigate carbon emissions have attracted financial interest that has been framed in terms of a modern "gold rush." However, various voices have begun to emerge and have been covered in the UK newspapers that criticize some of these schemes. This critique of the carbon offsetting market switched from the gold rush to the cowboy metaphor and framed carbon offsetting not as a desirable financial opportunity but as an activity of dubious moral quality, an activity undertaken by "cowboys."

The public's newfound awareness of climate change and their increasing desire to act on it has created a huge market demand. A few offset companies and charities have existed for quite some time but a great number of newly established ones are said to be "jumping on the bandwagon" (Sunday TimesBrown, 29/October/2007) and joining their ranks. Some of 
these companies - whose credentials and intents may be of a dubious nature and who are accused of seeking merely to exploit the market - are portrayed in the UK newspaper corpus as conmen, charlatans, and most prevalently: cowboys!

“Carbon offsetting is more about salving one's conscience than solving the problem of climate change,' said Duncan McLaren, chief executive of Friends of the Earth Scotland, warning that "carbon cowboys" could damage real efforts to combat global warming (Sunday HeraldEdwards, 15/July/2007).

Criticism of the voluntary offset market using cowboy imagery is often found in articles responding to events such as the release of the Tufts Climate Initiative's report: Voluntary Offsets For Air-Travel Carbon Emissions: Evaluation and Recommendations of Voluntary Offset Companies (Kollmuss \& Bowell, 2006), the Government's consultation on establishing a Voluntary Offset standard (DEFRA, 2007) and newspapers' own inquiries into the emerging market.

The UK newspaper articles invoke the lawlessness of the Wild West to warn consumers that this market, still in its infancy, is having some serious teething pains. As the “Consumers” Guide to Retail Carbon Offset Providers points out, "[c]onsumers would benefit from a clear-cut "seal-of-approval" for retail offsets" (Clear Air-Cool Planet, 2006, p. iii). In this context, references to cowboys are most often found in the article titles and within quotes from industry sources (UK newspaper corpus):

The fast-growing but increasingly criticized carbon offset industry is at risk of being discredited by “cowboy" operators unless it draws up a recognizable set of standards that customers can trust, one of the most senior figures in the sector has warned (The Formatted: Font: Not Italic Guardian (Financial Pages)Macalister, 18/June/2007). 
Offsetting chief warns of carbon cowboys: Lack of standards a threat to fledgling business. Growing evidence some plans cannot be trusted [Headline]

(GuardianMacalister, 18/June/2007).

The government launched itself into the growing debate over "cowboy" carbon

offsetting companies last week by announcing plans to "bring clarity" to the booming industry (The ObserverRobbins, 21/January/2007).

We have seen that gold rush imagery has been used to promote carbon offsetting schemes to those willing to gamble financial investments, whereas cowboy imagery has been used to criticize carbon offsetting schemes and question whether they can be trusted by consumers. What effect such framing has on the actual behavior of investors or consumers, whether such framing informs their actions of buying into carbon offsetting schemes or not, cannot be decided on the basis of our descriptive analysis. However, description of framing content (i.e. language, values, symbols, myths, and metaphors) can not only increase our understanding of media framing for this topic, but also assist in the identification of conflicting ideas. The awareness of problematic issues in the framing of carbon mitigation initiatives may lead to the creation of alternative frames or communication devices (Reese, 2003).

\section{Conclusions}

Two types of metaphorical framing emerged from the study of UK press coverage devoted to the business of carbon offsetting and emissions trading: metaphorical combinations urging greed and others urging caution. The words "gold rush" and "cowboy" were found to be used
Comment [a1]: Same as above remove?

Formatted: Font: Not Italic

Formatted: Font: Not Italic 
either to highlight the romantic aspects of the Wild West or to caution against the "permissiveness" that the Wild West can connote and the dangers posed by greed and exploitation. On the one hand, the gold rush metaphor scenario is used positively when describing the excitement associated with the new financial opportunities presented by carbon mitigation schemes. Efforts to reduce the severity of global warming have proven lucrative; here green is said to be gold. On the other hand, the use of "carbon cowboys" (similar perhaps to "cowboy builders") cautions against companies exploiting people here and in the developing world and draws attention to the dangers of profiteers raking in profits from "green business" (O’Neill, 2007). Here the unregulated terrain of carbon offsetting, seen as suffering from the lack of both legal and ethical standards, is compared to the lawlessness of the Wild West and particularly of "cowboys."

The gold rush and Wild West/cowboy metaphor scenarios used in the press foreground what we should worry and/or be cautious about, e.g. the exploitation of nature, resources and people, or what one should be excited about, e.g. the romantic pioneer ideals of “conquering" not only the Wild West (Turner, 19201, p. 269) but nature itself. Such metaphors also background the operation itself (in this case, the still problematic nature of offsetting). As a result, the indirect mechanism of offsetting, through the purchase of carbon credits instead of the direct reduction of emissions, is framed as fine in principle. If there is a problem, it is seen to lie elsewhere, mainly in the (greedy or bad) corporate world.

More than a century ago the American historian Frederick Jackson Turner published a seminal essay entitled "The Significance of the Frontier in American History" which advanced the so-called "Frontier Thesis" of American history". He argued that the growth of the American nation would inevitably destroy the frontier as an open living wilderness, which had initially contributed to the creation of the nation's character. We should perhaps 
ask ourselves whether framing carbon offsetting in terms of gold rush, cowboy and Wild West imagery and associated scenarios and assumptions might, in a not entirely dissimilar way, contribute in the long run to the destruction or perversion of the purpose for which carbon mitigation schemes were actually put in place: namely saving the planet. Those studying environmental communication might therefore want to continue to monitor the language used to frame carbon mitigation activities in the future. Language can, in this context, perhaps serve as a litmus test used to signal trouble ahead.

It is slightly ironic to note that Turner's frontier hypothesis was itself built on metaphors, images, myths and symbols, foremost perhaps the myth of the forest (Smith 1950; Coleman, 1966). Actions intended to save not only the forests but the whole of the planet in turn came to be shaped by myths associated with the "conquest" of the West, the conquest and exploitation of nature and in particular the gold rush mythology that contributed so much to the destruction of the wild forests that Turner loved.

We can only speculate over whether and when the current green gold rush bubble will burst and whether in the process, the Earth will become a safer or more hazardous place to live on. However, being aware of the myths and metaphors that frame this latest gold rush might help us see the limitations of this enterprise. As Brown (1976, p. 25) notes, "awareness of our use of metaphor provides an escape hatch from the prison house of language, or at least lets us know how we are confined. Such awareness [...] enables us to see the metaphoric in what is taken as literal, an act of unmasking."

It is too early to say whether carbon offsetting schemes become yet another "cowboy economy," where industries metaphorically "leave their campfire ashes behind and move on to a new frontier??" (Considine, 2002).B, but one has to ask: what What if there are no frontiers left? 


\section{Acknowledgements}

We would like to thank Florence Gohard for collecting the initial data set for us and starting the analysis, Mike Hulme for valuable comments and Nico Mouton for alerting us to the work of Frederick Jackson Turner. Thanks also to the three anonymous reviewers for their helpful criticisms and suggestions. We gratefully acknowledge funding from the Economic and Social Research Council, grant number: RES-062-23-1256. 


\section{Notes}

\footnotetext{
${ }^{1}$ This research will be carried out by the authors of this article in a project funded by the
} Economic and Social Research Council entitled 'Carbon Compounds: Lexical creativity and discourse formations in the context of climate change' (2008-2010).

${ }^{2}$ Karl Friedrich May (1842-1912) was one of the best selling German writers of all time, noted mainly for books set in the American Old West and similar books set in the Orient and Middle East (see Wikipedia).

${ }^{3}$ Throughout the following analysis our emphasis on particular instances of language use (metaphors and related compounds) in quotations will be registered by the use of emboldened text.

${ }^{4}$ Jatropha is a plant native to Central America. Its seeds are processed to produce oil that can be used in a standard diesel engine, while the residue can also be processed into biomass to power electricity plants (see Wikipedia).

$\underline{{ }^{5} \text { Lexis Nexis does not give information about URLS or page numbers. Quotes from press }}$ sources will be followed by a reference to author, if available, and date of publication. In the list of references readers can also find information about the title of the article and its source.

${ }^{6}$ All the articles were retrieved on 10 October 2007, which is therefore the end date of the time span searched.

${ }^{7}$ A detailed overview of emissions trading and its problems is provided in the special edition of Climate Policy 2006 (4).

${ }^{8}$ It should be noted that this boom as well as the framing in terms of gold rush continues up to the present day (September, 2008) as can be seen from the print and Internet media. For example, in an Internet article titled 'Green Energy Gold Rush Carries On Despite Credit 
Crunch, UNEP Finds' we find: '”Just as thousands were drawn to California and the Klondike in the late 1800 s, the green energy gold rush is attracting legions of modern day prospectors in all parts of the globe," said Steiner, who is also a UN Under-Secretary General' (Burger, 2008; see also Pearce, 2008).

${ }^{9}$ The essay was presented to a special meeting of the American Historical Association at the World's Columbian Exposition on July 12, 1893. It has been incorporated into Turner's $192 \underline{0} 4$ book, The Frontier in American History, as Chapter I. 


\section{References}

Anonymous (2007, July 27). Poison plant could help to cure the planet. The Times.
Anonymous (2006, October 26-) Green is good. The Times.

Formatted: Font: Not Bold Formatted: Font: Not Bold, Italic

Formatted: Font: Not Bold

Formatted: Font: Italic

Formatted: Font: Not Bold

Barthes, R. (1970). Mythologies. Paris: Seuil.

Bayon, R., Hawn, A. and Hamilton, K. (2007). Voluntary Carbon Markets: An international business guide to what they are and how they work. London: Earthscan.

Formatted: Indent: Left: $0 \mathrm{~cm}$, First line: $0 \mathrm{~cm}$

Beckley, R. M. (2005). The cowboy economy. University of Michigan. Retrieved September 16, 2007, from: http://www.tcaup.umich.edu/urp/cowboyeconomy.html.

Blodgett, P. (1999). Land of Golden Dreams: California in the Gold Rush Decade, 1848 1858. San Marino: Huntington Library.

Boykoff M. and $\underline{\&}$ Boykoff, J. (2007). Climate change and journalistic norms: A case-study of U.S. mass-media coverage. Geoforum 38(6), 1190-1204. 
Bream, R., S. Fidler and\& F. Harvey. (2007, April 26). Industry caught in 'carbon credit' smokescreen. Financial Times.

Formatted: English (U.S.)

Brooymans, H. (2007). ENERGY Green gold or fool's gold? Retrieved 1 September, 2007, from: http://www.uofaweb.ualberta.ca/govrel/news.cfm?story=59502.

Brossard, D., Shanahan, J.,\& McComas, K., (2000). Is mass media coverage of global warming culturally bound? A comparison of French and American coverage of global climate change. In: Proceedings of Climate Change Communication Conference, vol. B2, University of Waterloo, pp. 9-10.

Brown, J. (2006, October). Carbon offset deals are trading in guilt. The Sunday Times.

Brown, R.H. (1976). Social theory as metaphor: On the logic of discovery for the sciences of conduct. Theory and Society 3, 1-29.

Browne, A. (2006, November 4). The green goldrush that is creating multimillionaires. The Times.

Burger, A. (2008). Green Energy Gold Rush Carries On Despite Credit Crunch, UNEP Finds. Retrieved September 28, 2008, from: http://www.globalwarmingisreal.com/blog/category/climate-change-and-business.
Formatted: Font: $12 \mathrm{pt}$ Formatted: Font: $12 \mathrm{pt}$, Italic Formatted: Font: $12 \mathrm{pt}$ Formatted: 1st Paragraph Formatted: Indent: Left: $0 \mathrm{~cm}$ 
Carvalho, A. (2005). Representing the politics of the greenhouse effect: discursive strategies in the British media. Critical Discourse Studies 2 (1), 1-29.

Carvalho, A., \& Burgess, J. (2005). Cultural circuits of climate change in U.K. broadsheet newspapers, 1985-2003. Society for Risk Analysis 25 (6), 1457-1469.

Climate Policy (2006). Special issue on Emissions Trading, 6 (4).

Coleman, W. (1966). Science and symbol in the Turner Frontier Hypothesis. American Historical Review, 72, 22-49.

Collinson, P. (2007). How green turned into gold. The Guardian unlimited, Saturday June 2. Retrieved September 4, 2009:: http://www.guardian.co.uk/money/2007/jun/02/fundsbondstrusts.ethicalmoney

Considine, T. J. (2002). Green economics. Penn State online research. Retrieved October 12, 2007 from: http://www.rps.psu.edu/0205/economics.html

Cool Air-Cool Planet. (2006). A Consumer's guide to retail carbon offset providers. Retrieved April 3, 2008, from: http://www.cleanaircoolplanet.org/ConsumersGuidetoCarbonOffsets.pdf. 
Davey, J. (2007, July 15). Smile that spells biofuels: Farmer Rash has a spring in his step again because of green diesel. The Sunday Times.

Formatted: Font: Italic

Davies, N. (2007, June 2). Truth about Kyoto: huge profits, little carbon saved. The

Formatted: Font: Italic Guardian.

Dawkins, R. (1976). The Selfish Gene. Oxford: Oxford University Press.

DEFRA [Department for Environment, Farming and Rural Affairs] (2005). Climate change: Carbon offsetting. Retrieved September 27, 2008, from: http://www.defra.gov.uk/environment/climatechange/uk/carbonoffset/

Driesbach, J., Jones, H., \& Holland, K. (1998). Art of the Gold Rush. Berkeley: University of California Press.

Edwards, R. (2007, July 14) Black marks for firms who exaggerate impact of carbon offsetting schemes. Sunday Herald.

Formatted: Font: Italic

Fussell, E. (1965). Frontier: American Literature and the American West. Princeton, NJ: Princeton University Press.

Gitlin, T. (1980). The Whole World Is Watching: Mass Media in the Making and Unmaking of the New Left. Berkeley, CA, Los Angeles, CA \& London, U.K.: University of California Press. 
Hallwell, B. (2001). Organic gold rush. World Watch Magazine, 14 (3). Retrieved September 1, 2007, from: http://www.worldwatch.org/node/501.

Harvey, F. (2007, April 27). Offsetting business seen as a 'booming industry'. Financial

Formatted: Font: Italic

Times.

Harré, R., Brøckmeier, J., \& Mühlhüusler, P. (1999). Greenspeak: A Study of Envirønmental Disceurse Lenden: Sage.

Formatted: Font: Italic

Holland, P. (2007, April 5). Investing Wisely in the Green Rush. Business Week.

Formatted: Font: Italic

Harrisen, R., Newholm, T., \& Shaw, D. (Eds) (2005). The Ethical Consumer. Londen: Sage.

Hogan, J. (2005). Alarm bells rings louder for climate change. Retrieved Oetober 15, 2007 from: http://www.newscientist.com/article/dn6970.html.

Hooper, R. (2005). Struggle over (green) gold rush. Wired. Retrieved September 10, 2007, from: http://www.wired.com/medtech/health/news/2005/04/67244.

Hulme, M. (2007). Newspaper scare headlines can be counter-productive. Nature, 445, 818.

Iyengar, S. (1987). Television news and citizens' explanations of national affairs. American Political Science Review, 81, 815-831. 
Jameson, A. (2006, June 28). Carbon traders win in rush to be green. The Times.

Kharif, O. (2004, November 11). Betting on Tools that Power Blogs. Business Week.

Kollmuss, A., \& Bowell, B. (2006). Tufts Climate Initiative. Retrieved October 12, 2007, from: http://www.cdmgoldstandard.org/uploads/file/TCI_Carbon_Offsets_Paper_Jan07.pdf

Koteyko, N., Brown, B., \& Crawford, P. (in press2008). The dead parrot and the dying swan: The role of metaphor scenarios in UK press coverage of avian flu in the UK in 20052006. Metaphor \& Symbol, 23 (4).

Lakoff, G. \& M. Johnson. (1980). Metaphors We Live By. Chicago: Chicago University Press.

Landell Mills, N., \& Porras, T. I. (2002). 'Silver bullet or fools' gold? A global review of

markets for forest environmental services and their impact on the poor'. Instruments

for sustainable private sector forestry series. London: International Institute for

Envirenment and Development.

Lofthouse, R. (2007). The Green Klondike. Retrieved October 5, 2007, from: http://cnbceb.com/2007/01/01/the-green-klondike.
Formatted: Font: Not Bold

Formatted: Font: Not Bold

Formatted: Font: Not Bold

Formatted: Font: Not Bold, Italic

Formatted: Font: Italic

Formatted: Indent: Left: $0 \mathrm{~cm}$, First line: $0 \mathrm{~cm}$
Formatted: Font: $12 \mathrm{pt}$

Formatted: 1st Paragraph, Indent: Left: $0 \mathrm{~cm}$, Hanging: $1.25 \mathrm{~cm}$ 
Lux Research Report (2005). Nanotechnology Gold Rush Yields Crowded, Entangled

Patents. Retrieved 5 October, 2007, from:

http://www.nanotech-now.com/news.cgi?story_id=09134

Macalister, T. (2007, June 18). Offsetting chief warns of carbon cowboys: Lack of standards + a threat to fledgling business Growing evidence some plans cannot be trusted. The

Formatted: Font: Not Bold Formatted: Indent: Left: $0 \mathrm{~cm}$, Hanging: $1.27 \mathrm{~cm}$

Formatted: Font: Italic

Guardian. Formatted: Font: Not Bold

Formatted: Indent: Left: $0 \mathrm{~cm}$

MacCrone, A. (2005, August 7). London leads carbon market. The Sunday Times.

Formatted: Font: Italic

Morse, K. (2003). The nature of gold: An environmental history of the Klondike Gold Rush. Seattle: University of Washington Press.

Mühlhäusler, P. (1999). Metaphor and metonymy in environmental advertising. AAA:

Arbeiten aus Anglistik und Amerikanistik, 24(2), 167-180.

Musolff, A. (2006). Metaphor scenarios in public discourse. Metaphor and Symbol, 21 (1), $23-38$.

Nerlich, B. (2004). Towards a cultural understanding of agriculture: The case of the 'war' on foot and mouth disease. Agriculture and Human Values, 21(1), 15-25. 
Nerlich, B., \& Halliday, C. (2007). Avian flu: The creation of expectations in the interplay between science and the media. Sociology of Health and Illness, 29(1), 46-65.

$\underline{\text { O’Connell1, D. and G. Ringshaw (2006, October 29). Focus: The City goes green. The }}$

Formatted: Font: Italic Sunday Times.

O’Neill, B. (2007). Is carbon-offsetting just eco-enslavement? Spiked online. Retrieved $\underline{\text { September 10, 2007, from: }}$

http://www.spiked-online.com/index.php?/site/article/3788

Oxford English Dictionary (online): http://www.oed.com/

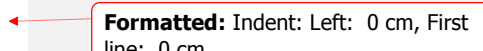

line: $0 \mathrm{~cm}$

O’Neill, B. (2007). Is carbon- offsetting justeco-nstavement? Spiked online. Retrieved September 10, 2007, from:

http://www.spiked-online.com/index.php?/site/article/3788

$4 \quad$ Formatted: Indent: Hanging: 1.27

Formatted: Indent: Left: $-1.27 \mathrm{~cm}$, Hanging: $1.27 \mathrm{~cm}$

Pearce, F. (2008). Carbon trading: dirty, sexy money. New Scientist, 2652. Retrieved 25

September, 2008 from: http://www.newscientist.com/article.ns?id=mg19826521.600

Petersen, A. (2005). The metaphors of risk: Biotechnology in the news. Health Risk and Society, 7(3), 203-208. 
Philipkoski, K. (2004). The stem cell gold rush. Wired. Retrieved September 10, 2007, from: http://www.wired.com/medtech/health/news/2004/11/65588

Pratchett, T. (2007). Wintersmith. NewYork: Doubleday and Co.

Formatted: Font: Italic

Reese, O.H. (2003). Prologue - Framing public life: A bridging model for media research. In S.D. Reese, O.H. Gandy Jr., \& A.E. Grant (Eds.), Framing Public Life (pp. 7-31).

Robbins, T. (2007, January 21). Escape: Arrivals: The hot topic: Carbon cowboys face crackdown. The Observer.

Formatted: Font: Italic

Roberts, B. (2004). Review of Kathryn Morse. The Nature of Gold: An Environmental History of the Klondike Gold Rush. American Historical Review, 109(5), 1586-1587.

Shrimsley, R. (2007, July 5). Don't care? Offset notebook. Financial Times.

Formatted: Font: Italic

Robins, N. (2006). Fear, greed and finance. New Statesman. Retrieved September 20, 2007 , from: http://www.newstatesman.com/200605150071

Smith, H. N. (1950). Virgin lands: The American West as symbol and myth. Cambridge: Harvard University Press.

Stern, N. (2007). The economics of climate change: The Stern review. Cambridge: Cambridge University Press. 
Thornes, J., \& Randalls, S. (2007). Commodifying the atmosphere: pennies from heaven? Geografiska Annaler, Series A: Physical Geography, 89 (4), 273-285.

Turner, F. (1920). The Frontier in American History. New York: Henry Holt and Company.

Vico, G. (1725/1948). The New Science of Giambattista Vico, Revised edition, T.G. Bergin/M.H. Fisch (Eds. and Trans.), Ithaca, NY: Cornell University Press.

Zinken, J., Hellsten, N., \& Nerlich, B. (2008). Discourse metaphors. In Frank, R. M., Dirven, R., Ziemke, T., Bernardez, E. (Eds.), Body, Language and Mind. vol. 2: Sociocultural situatedness (pp. 363-386). Amsterdam: John Benjamins.

Weingart, P., Engels, A., \& Pansegrau, P. (2000). Risks of communication: discourses Formatted: Swedish (Sweden) on climate change in science, politics, and the mass media. Public

Understanding of Science 9, 261-283. 